\begin{tabular}{|c|l|}
\hline Title & $\begin{array}{l}\text { A naerobic treatment of municipal wastewater at ambient temperature: A nalysis of archaeal community structure and } \\
\text { recovery of dissolved methane }\end{array}$ \\
\hline Author(s) & $\begin{array}{l}\text { Bandara, Wasal a M.K.R.T.W.; Kindaichi, Tomonori; Satoh, Hisashi; Sasakawa, Manabu; Nakahara, Y oshihito; } \\
\text { Takahashi, Masahiro; Okabe, Satoshi }\end{array}$ \\
\hline Citation & $\begin{array}{l}\text { Water Research, 46/17), 5756-5764 } \\
\text { https://doi.org/10.1016j.watres.2012.07.061 }\end{array}$ \\
\hline Issue Date & 2012-11-01 \\
\hline Doc URL & http:/hdl.handle.net/2115/50385 \\
\hline Type & article (author version) \\
\hline File Information & WR46-17_5756-5764.pdf \\
\hline
\end{tabular}

Instructions for use 
For submission to Water Research as a Full Paper

\section{Anaerobic treatment of municipal wastewater at ambient temperature: Analysis of archaeal community structure and recovery of dissolved methane}

Wasala M. K. R. T. W. Bandara ${ }^{\mathrm{a}}$, Tomonori Kindaichi ${ }^{\mathrm{b}}$, Hisashi Satoh ${ }^{\mathrm{a}, *}$, Manabu Sasakawa $^{\mathrm{c}}$, Yoshihito Nakahara ${ }^{\mathrm{c}}$, Masahiro Takahashi $^{\mathrm{a}}$, and Satoshi Okabe

a Division of Environmental Engineering, Faculty of Engineering, Hokkaido University, North-13, West-8, Sapporo 060-8628, Japan

b Department of Civil and Environmental Engineering, Graduate School of Engineering, Hiroshima University, 1-4-1 Kagamiyama, Higashihiroshima, Hiroshima 739-8527, Japan

c Mitsubishi Rayon Co., Ltd., Aqua Development Center, 4-1-2 Ushikawadori, Toyohashi, Aichi 440-8601, Japan

*Corresponding author.

Mailing address:

Hisashi Satoh

Division of Environmental Engineering, Faculty of Engineering, Hokkaido University, North-13, West-8, Sapporo 060-8628, Japan. 
Tel: +81-(0)11-706-6277

Fax: +81-(0)11-706-6277

E-mail: qsatoh@eng.hokudai.ac.jp 


\begin{abstract}
Anaerobic treatment is an attractive option for the biological treatment of municipal wastewater. In this study, municipal wastewater was anaerobically treated with a bench-scale upflow anaerobic sludge blanket (UASB) reactor at temperatures from $6-31^{\circ} \mathrm{C}$ for 18 months to investigate total chemical oxygen demand (COD) removal efficiency, archaeal community structure, and dissolved methane $\left(\mathrm{D}-\mathrm{CH}_{4}\right)$ recovery efficiency. The COD removal efficiency was more than 50\% in summer and below $40 \%$ in winter with no evolution of biogas. Analysis of the archaeal community structures of the granular sludge from the UASB using 16S rRNA gene-cloning indicated that after microorganisms had adapted to low temperatures, the archaeal community had a lower diversity and the relative abundance of acetoclastic methanogens decreased together with an increase in hydrogenotrophic methanogens. D- $\mathrm{CH}_{4}$, which was detected in the UASB effluent throughout the operation, could be collected with a degassing membrane. The ratio of the collection to recovery rates was $60 \%$ in summer and $100 \%$ in winter. For anaerobic treatment of municipal wastewater at lower temperatures, hydrogenotrophic methanogens play an important role in COD removal and $\mathrm{D}-\mathrm{CH}_{4}$ can be collected to reduce greenhouse gas emissions and avoid wastage of energy resources.
\end{abstract}

Keywords: Archaeal community structure; Degassing membrane; Dissolved methane; Municipal wastewater; Psychrophilic condition; Upflow anaerobic sludge blanket process 


\section{Introduction}

Anaerobic treatment is an attractive option for the biological treatment of municipal wastewater (Latif et al., 2011; Kayranli and Ugurlu, 2011; Lew et al., 2011; Elefsiniotis et al., 1996). It has numerous advantages, including the generation of useful energy (i.e., biogas), no energy requirement for aeration, and the reduction of the cost of sludge treatment. In temperate regions, the ambient temperature of municipal wastewaters is considerably lower than the optimum value for anaerobic treatment processes (Latif et al., 2011; Dhaked et al., 2010). To operate anaerobic treatment processes under mesophilic conditions $\left(30^{\circ} \mathrm{C}-40^{\circ} \mathrm{C}\right)$, a significant input of energy is required to heat the influent wastewaters, resulting in a loss of energy. Thus, the operation of an anaerobic bioreactor for municipal wastewater treatment at ambient temperature in temperate regions offers economic advantages over the operation under mesophilic or thermophilic $\left(45^{\circ} \mathrm{C}-60^{\circ} \mathrm{C}\right)$ conditions.

Anaerobic treatment of low-strength wastewaters at ambient or low temperatures has recently been successfully demonstrated (Latif et al., 2011; Kayranli and Ugurlu, 2011; Lew et al., 2011; Urban et al., 2007; Alvarez et al., 2008). However, further studies are required to anaerobically treat low-strength municipal wastewaters at low temperatures. Specifically, chemical oxygen demand (COD) removal rate and methane $\left(\mathrm{CH}_{4}\right)$ production rate are low owing to lower microbial activity under psychrophilic $\left(<20^{\circ} \mathrm{C}\right)$ conditions (Latif et al., 2011; Dhaked et al., 2010). The economic feasibility of the long-term low-temperature anaerobic treatment relies on 
sufficient microbial activity to ensure reliable wastewater treatment. However, little is known about psychrophilic methanogenesis. In some systems mesophilic methanogenic communities that adapt to low temperatures contributed to methanogenesis, in contrast, specific psychrophilic methanogenic communities carried out methanogenesis in others. (Dhaked et al., 2010). Greater insights into the relationship between process performance and microbial characteristics in the anaerobic treatment of municipal wastewaters at low temperature are required to achieve stable COD removal and biogas production.

It is also important to consider dissolved methane gas $\left(\mathrm{D}-\mathrm{CH}_{4}\right)$ in the anaerobic treatment of municipal wastewaters. D- $\mathrm{CH}_{4}$ in anaerobic treatment effluent is not usually recovered, which results in greenhouse gas emission from the anaerobic treatment process and loss of a potential energy resource (Urban et al., 2007). The loss of $\mathrm{D}-\mathrm{CH}_{4}$ is enhanced at lower temperatures because of the increase in $\mathrm{CH}_{4}$ solubility at reduced temperatures (Bandara et al., 2011). Thus, it is the case with the anaerobic treatment of municipal wastewaters at low temperatures. In these processes, as much D- $\mathrm{CH}_{4}$ as possible from the anaerobic treatment effluent should be collected. Several studies have investigated the collection of $\mathrm{D}-\mathrm{CH}_{4}$ from the anaerobic treatment of wastewaters by physical gasification based on gas-liquid equilibrium and mixing with gas or a paddle (Hatamoto et al., 2010; Matsuura et al., 2010; Hartley and Lant, 2006; Pauss et al., 1990). However, the collection efficiency of D-CH 4 was low and/or the recovered $\mathrm{CH}_{4}$ gas concentration was low using these technologies. Our previous research demonstrated that degasification with a degassing membrane (DM) could 
effectively collect D- $\mathrm{CH}_{4}$ without reducing its concentration in the anaerobic treatment of a low-strength synthetic wastewater at low temperature (Bandara et al., 2011). The DM only allows gas molecules to pass through the non-porous layer of the DM (Bandara et al., 2011; Matsunaga et al., 2012). Thus, the DM effectively separates dissolved gases from the liquid. In the present research study, we operated a bench-scale upflow anaerobic sludge blanket (UASB) reactor, of which the liquid outlet was connected to the DM reactor, to treat raw municipal wastewater at ambient temperature (from $6^{\circ} \mathrm{C}$ to $31^{\circ} \mathrm{C}$ ) over 18 months. The performance of the UASB reactor was monitored. The archaeal community structures of the UASB reactor were analyzed using $16 \mathrm{~S}$ rRNA gene-cloning techniques. Additionally, the $\mathrm{D}-\mathrm{CH}_{4}$ collection efficiency by degasification was investigated.

\section{Materials and methods}

2.1. Experimental setup and operating conditions

A UASB reactor (height, $80 \mathrm{~cm}$; diameter, $5 \mathrm{~cm}$; working volume, $1.6 \mathrm{~L}$ ) was operated from January 2010 to June 2011 . The reactor was inoculated with $0.7 \mathrm{~L}$ of anaerobic granular sludge obtained from the bench-scale UASB reactor operated in our laboratory (Bandara et al., 2011). It had total and volatile solids concentrations of $24 \mathrm{~g} / \mathrm{L}$ and $18 \mathrm{~g} / \mathrm{L}$, respectively. The UASB reactor was fed with domestic wastewater from the Souseigawa municipal wastewater treatment plant in Sapporo, Japan (Okabe 
et al., 1999). The concentrations (average \pm standard deviation) of total COD (T-COD) and the dissolved fraction of COD (D-COD), and $\mathrm{pH}$ in the wastewater were $173 \pm 38$ $\mathrm{mg} / \mathrm{L}, 78 \pm 17 \mathrm{mg} / \mathrm{L}$, and $7.2 \pm 0.2$, respectively. The hydraulic retention time (HRT) was changed in response to changes in the COD removal efficiency (see Figure 1b). The temperature, which was not controlled, varied from $6^{\circ} \mathrm{C}$ to $31^{\circ} \mathrm{C}$. A 20 -cm-high filter media (polyester nonwoven fabric sheets; Japan Vilene Co., Ltd., Tokyo, Japan) was installed in the upper part of the UASB reactor on June 22, 2010, to avoid biomass washout. A DM reactor was connected to the effluent of the UASB reactor to collect the residual $\mathrm{D}-\mathrm{CH}_{4}$ in the effluent according to a study described previously. The characteristics of the DM have been described in detail elsewhere (Bandara et al., 2011). D- $\mathrm{CH}_{4}$ was collected into the lumen of the hollow fibers of the DM using a vacuum pump and the transmembrane pressure was set to $80 \mathrm{kPa}$ using a vacuum gauge. A transmembrane pressure of $97 \mathrm{kPa}$ was also tested after April 25, 2011, to investigate the effect of transmembrane pressure on $\mathrm{D}-\mathrm{CH}_{4}$ collection efficiency.

2.2. DNA extraction and PCR amplification of $16 \mathrm{~S}$ rRNA genes

Total DNA was extracted from the granular sludge inoculum, termed INO, and a mature granular sludge, termed PSY, in the UASB reactor on day 416 (February 15, 2011) using a Fast DNA spin kit (MP Biomedicals, Irvine, CA) according to the manufacturer's instructions. To construct archaeal clone libraries, the 16S rRNA gene fragments from the isolated total DNA were amplified using a ONE Shot LA PCR 
MIX kit (TaKaRa Bio Inc., Ohtsu, Japan) and a primer set of arc109f (Lueders and Friedrich, 2000) and univ1390r (Zheng et al., 1996). The PCR condition for the archaea was as follows: 5 min of initial denaturation at $94^{\circ} \mathrm{C}$, followed by 25 cycles of $30 \mathrm{~s}$ at $94^{\circ} \mathrm{C}, 30 \mathrm{~s}$ at $50^{\circ} \mathrm{C}$, and $1 \mathrm{~min}$ at $72^{\circ} \mathrm{C}$. The final extension was conducted for 5 min at $72^{\circ} \mathrm{C}$. All PCRs were performed using a total volume of $50 \mu \mathrm{L}$ containing $1 \mu \mathrm{g}$ of DNA as the template. The PCR products were electrophoresed in a $1 \%$ (wt/vol) agarose gel.

2.3. Clone library construction and phylogenetic analysis

The archaeal clone libraries were constructed using previously described methods (Kindaichi et al., 2011). DNA sequencing was performed by Dragon Genomics Center, TaKaRa Bio Inc. (Yokkaichi, Japan). The 16S rRNA gene sequences from the archaeal clone libraries (1,281 bp) were imported and aligned using Integrated Aligners in the ARB software (Ludwig et al., 2004) with the database SSU Ref NR 106 dataset (Pruesse et al., 2007). Sequences with 97\% or higher similarity were grouped into operational taxonomic units (OTUs) using the Distance matrix methods with the similarity correction in the ARB software. Phylogenetic trees were constructed using the neighbor-joining (Saitou and Nei, 1987) with jukes-cantor correction model and maximum parsimony (Phylip DNAPARS) approaches using default settings in the ARB software. A bootstrap resampling analysis for 1,000 replicates was conducted to estimate the confidence of tree topologies. The 16S rRNA 
gene sequence data obtained in this study were deposited in the

GenBank/EMBL/DDBJ databases under accession numbers AB123456 to AB123456.

\subsection{Sampling and analysis methods}

$\mathrm{CH}_{4}$ concentrations in the headspace of the UASB reactor and inside the DM were measured using a gas chromatography system (Bandara et al., 2011). Dissolved gas concentrations were measured using the headspace method (Bandara et al., 2011). The concentrations of T-COD and D-COD in the influent and effluent of the UASB and DM reactors were measured using the Hach method (Method 8000) (Bandara et al., 2011). The concentration of the particulate fraction of COD (P-COD) was calculated by subtracting the D-COD concentration from the T-COD concentration. The oxidation-reduction potential (ORP) and $\mathrm{pH}$ were directly determined using ORP and $\mathrm{pH}$ electrodes, respectively.

On the basis of these measurements and liquid flow rates, the rates (mg $\mathrm{COD} /$ day) of $\mathrm{CH}_{4}$ evolved into the UASB headspace $\left(\mathrm{R}\left(\mathrm{CH}_{4}\right)_{\text {evo }}\right), \mathrm{D}-\mathrm{CH}_{4}$ discharged from the UASB reactor $\left(\mathrm{R}\left(\mathrm{D}-\mathrm{CH}_{4}\right)_{\mathrm{UASB}}\right), \mathrm{D}-\mathrm{CH}_{4}$ collected with the DM $\left(\mathrm{R}\left(\mathrm{D}-\mathrm{CH}_{4}\right)_{\mathrm{col}}\right)$, and $\mathrm{D}-\mathrm{CH}_{4}$ discharged from the $\mathrm{DM}$ reactor $\left(\mathrm{R}\left(\mathrm{D}-\mathrm{CH}_{4}\right)_{\text {dis }}\right)$ were calculated. Furthermore, the D-CH 4 collection efficiency was calculated as $\mathrm{D}-\mathrm{CH}_{4}$ collection efficiency $=\frac{\mathrm{R}\left(\mathrm{D}-\mathrm{CH}_{4}\right)_{\text {col }}}{\mathrm{R}\left(\mathrm{D}-\mathrm{CH}_{4}\right)_{\mathrm{UASB}}}$ The $\mathrm{CH}_{4}$ recovery efficiency was calculated as $\mathrm{CH}_{4}$ recovery efficiency $=\frac{\mathrm{R}\left(\mathrm{CH}_{4}\right)_{\mathrm{rec}}}{\mathrm{T}-\mathrm{R}\left(\mathrm{CH}_{4}\right)}=\frac{\mathrm{R}\left(\mathrm{CH}_{4}\right)_{\mathrm{evo}}+\mathrm{R}\left(\mathrm{D}-\mathrm{CH}_{4}\right)_{\mathrm{col}}}{\mathrm{R}\left(\mathrm{CH}_{4}\right)_{\mathrm{evo}}+\mathrm{R}\left(\mathrm{D}-\mathrm{CH}_{4}\right)_{\mathrm{col}}+\mathrm{R}\left(\mathrm{D}-\mathrm{CH}_{4}\right)_{\mathrm{dis}}}$ 
Where $\mathrm{R}\left(\mathrm{CH}_{4}\right)_{\text {rec }}$ is the $\mathrm{CH}_{4}$ recovery rate (mg COD/day) defined as the sum of $\mathrm{R}\left(\mathrm{CH}_{4}\right)_{\text {evo }}$ and $\mathrm{R}\left(\mathrm{D}-\mathrm{CH}_{4}\right)_{\text {col }}$, and $\mathrm{T}-\mathrm{R}\left(\mathrm{CH}_{4}\right)$ is the total $\mathrm{CH}_{4}$ production rate $(\mathrm{mg}$ COD/day) defined as the sum of $\mathrm{R}\left(\mathrm{CH}_{4}\right)_{\mathrm{evo}}, \mathrm{R}\left(\mathrm{D}-\mathrm{CH}_{4}\right)_{\text {col }}$, and $\mathrm{R}\left(\mathrm{D}-\mathrm{CH}_{4}\right)_{\mathrm{dis}}$.

The amounts of suspended solids (SS) and volatile suspended solids (VSS) in the filter media and in the granular sludge ( $\mathrm{g}$ per reactor) were estimated and used as an indicator of microorganisms (Andrew et al., 2005). Biomass samples were taken from $100 \mathrm{~mL}$ of the filter media and $10 \mathrm{~mL}$ of the granular sludge. Then, the filtered samples were dried at $105^{\circ} \mathrm{C}$ and weighed to determine SS. To determine VSS, they were further burned at $550^{\circ} \mathrm{C}$ to allow volatile substances to evaporate.

\section{Results and discussion}

\subsection{Performance of the UASB reactor}

The bench-scale UASB reactor was operated at ambient temperature from January 2010 to June 2011. Changes in T-COD and D-COD concentrations in the influent, T-COD concentration in the effluent, and T-COD removal efficiency are observed (Figure 1a). The influent T-COD and D-COD concentrations were in the ranges $70-310 \mathrm{mg} / \mathrm{L}$ and $50-160 \mathrm{mg} / \mathrm{L}$, respectively. Based on the COD results, the municipal wastewater used in this study could be classified as a low-strength domestic wastewater (Tchobanoglous et al., 2003). The average ( \pm standard deviation) of the influent P-COD/T-COD ratio remained relatively constant $(0.56 \pm 0.05)$ throughout 
the operation.

Temperature, HRT, and $\mathrm{pH}$ in the UASB reactor are shown in Figure $1 \mathrm{~b}$. Temperature varied from $6^{\circ} \mathrm{C}$ to $31^{\circ} \mathrm{C}$ during the operation. HRT was adjusted in the range of $2-8 \mathrm{~h}$ in response to changes in the COD removal efficiency. The $\mathrm{pH}$ in the UASB reactor became lower than that in the influent after July 2010.

T-COD was not removed during the first winter (Figure 1a). Between July and October 2010 , the T-COD removal efficiency was in the range 50\%-71\%. The temperature ranged from $20^{\circ} \mathrm{C}$ to $31^{\circ} \mathrm{C}$ during this period (Figure $1 \mathrm{~b}$ ), indicating that temperature was a critical factor for effective COD removal. Although disintegration of the granules was observed during the operation, the average amounts of VSS in the granular bed increased from $78 \pm 15$ to $150 \pm 40 \mathrm{~g}$ per reactor by installation of the filter media on June 22, 2010 because of prevention of biomass washout. This is a common problem with the anaerobic treatment of low-strength wastewaters for short HRT (Latif et al., 2011). Enhancement of the retention and growth of biomass by the installation of the filter media may have contributed to the improvement in T-COD removal efficiency (Figure 1 $\underline{\mathrm{a}})$ and increase in $\mathrm{R}\left(\mathrm{CH}_{4}\right)_{\text {evo }}$ (see Figure $\underline{1 \mathrm{c}}$ ) between July and October 2010. The T-COD removal efficiency started to decrease at the beginning of Nov 2010 accompanying the temperature drop. This might be attributed to the low methanogenic activity at low temperatures (Dhaked et al., 2010). Volatile fatty acids (mainly acetic acid) were detected in winter, but not in summer, indicating that acidogenic activity was not inhibited compared to methanogenic activity at low temperatures. Subsequently, the T-COD removal efficiency gradually increased from 
$10 \%$ to around $60 \%$ in April 2011 owing to the gradual increase in temperature. The COD removal efficiency was lower $(<71 \%)$ in this study than those in UASB reactors treating high-strength wastewaters under mesophilic conditions (Latif et al., 2011). This might be because of the higher P-COD fraction of the municipal wastewater used in this study and the operation at ambient temperature (Figures 1a and 1b) (Alvarez et al., 2008). Table 1 summarizes the operating parameters and T-COD removal efficiencies of UASB reactors treating low-strength wastewaters under psychrophilic conditions reported in the previous studies. These results indicate that the treatment of low-strength wastewaters at low temperatures results in low COD removal efficiencies. Therefore, an aerobic post-treatment is needed to achieve the appropriate T-COD removal efficiency (Khan et al., 2011).

The biogas production rate and $\mathrm{R}\left(\mathrm{CH}_{4}\right)_{\text {evo }}$ in the UASB reactor are presented in Figure 1c. From January to May 2010, no biogas was evolved into the UASB headspace because of the low T-COD removal efficiency (Figure 1a). It should be noted that a barely detectable amount of $\mathrm{D}-\mathrm{CH}_{4}$ was found in the UASB reactor and D- $\mathrm{CH}_{4}$ was discharged from the DM reactor during this period (see Figure 3a). Biogas was evolved in summer. The $\mathrm{CH}_{4}$ concentrations in the UASB headspace and in the biogas collected with the DM were $50 \% \pm 11 \%$ and $52 \% \pm 8 \%$, respectively, from July to October, which are comparable to or lower than those when treating high-strength wastewaters (Latif et al., 2011; Bandara et al., 2011). Biogas evolution ceased again in the second winter season. Thereafter, biogas evolution occurred as temperature increased from May 2011. 


\subsection{Archaeal community structure}

To investigate the microbial community structure in the UASB reactor, archaeal clone libraries of INO and PSY were constructed. No chimeric sequences were detected in the clone libraries. We obtained 69 and 72 clones from the INO- and PSY-clone libraries, respectively. At least 5 archaeal groups at the order level including 15 different OTUs on the basis of more than $97 \%$ sequence similarity within an OTU were identified (Figure 2). It should be noted that there were no differences in the topology of the three trees generated using the neighbor-joining, the maximum-parsimony, and the maximum-likelihood methods. In the granular sludge inoculum, nine different OTUs were identified. Methanosaeta- and Methanobacterium-like clones comprised 57\% (39 out of 69 clones) and 28\% (19 out of 69 clones) of the INO-clone library, respectively. However, by day 416, a shift in the archaeal community structure was evident. The number of OTUs in the PSY-clone library had decreased to 6 , indicating that the archaeal community had a lower diversity after microorganisms had adapted to low temperatures. Although high levels of Methanosaeta-like acetoclastic methanogens were maintained in the PSY-clone library, the relative abundance of Methanosaeta concilii-like clones diminished and the relative abundance of Methanosaeta harundinacea-like clones increased in the granular sludge inoculum. The most frequently detected clones in the PSY-clone library were affiliated with Methanolinea tarda (21 out of 72 clones; detection 
frequency, 29\%). In addition, the clones affiliated with Methanobacterium beijingense comprised $7 \%$ (5 out of 72 clones) of the PSY-clone library. These two OTUs, which were absent in the INO-clone library, utilize $\mathrm{H}_{2}$ and formate for growth and methane production (Imachi et al., 2008; Ma et al., 2005).

Methanosaeta-like acetoclastic methanogens were dominant in the granular sludge inoculum, such that these species are believed to be competitive in established methanogenic communities (Zhang et al., 2012; McKeown et al., 2009a; Satoh et al., 2007; O'Reilly et al., 2009). In contrast, several studies have documented that methanogenesis predominantly proceeds through the hydrogenotrophic route in anaerobic bioreactors under psychrophilic conditions (O'Reilly et al., 2009, 2010; McKeown et al., 2009b; Connaughton et al., 2006; McHugh et al., 2004). Under psychrophilic conditions, improved thermodynamics of methane formation from $\mathrm{H}_{2} / \mathrm{CO}_{2}$, coupled with the enhanced solubility and therefore accessibility of $\mathrm{H}_{2} / \mathrm{CO}_{2}$ in the reactor liquor, are thought to account for this phenomenon (Lettinga et al., 2001). The observed granule disintegration during the operation might be attributed to a decrease in the relative abundance of the filamentous Methanosaeta, which are suggested to play an important role in the formation and maintenance of granular sludge in an anaerobic bioreactor (McHugh et al., 2005).

OTU PSY-e7 (11 out of 72) and PSY-e1 (1 out of 72), which were not detected in the INO-clone library, were affiliated with the deep-sea hydrothermal-vent euryarchaeotal group 6 (DHVEG-6) and the terrestrial miscellaneous group (TMEG) based on the SILVA taxonomy (Pruesse et al., 2007), respectively. Members of these 
groups have primarily been detected in habitats such as ocean water, coastal water, polar seawater, deep-sea hydrothermal vents, hypersaline microbial mat, and methanogenic granular sludge (Nunoura et al., 2008; Takai and Horikoshi, 1999; Robertson et al., 2009; Yashiro et al., 2011). The ecophysiology and functions of the groups remained unknown.

\subsection{Degasification with the DM}

Figure 3a shows D- $\mathrm{CH}_{4}$ concentrations discharged from the UASB and DM reactors. D- $\mathrm{CH}_{4}$ concentrations discharged from the DM reactor were clearly lower than those from the UASB reactor, indicating the residual D- $\mathrm{CH}_{4}$ in the effluent of the UASB reactor was successfully collected by the DM. The average D- $\mathrm{CH}_{4}$ concentrations discharged from the UASB and DM reactors were $51 \pm 12 \mathrm{mg} \mathrm{COD} / \mathrm{L}$ and $22 \pm 4 \mathrm{mg} \mathrm{COD} / \mathrm{L}$ from July to October 2010 , and $48 \pm 9 \mathrm{mg} \mathrm{COD} / \mathrm{L}$ and $16 \pm 3 \mathrm{mg}$ COD/L from December 2010 to March 2011, respectively. The average biogas flux through the DM was $55 \pm 10 \mathrm{~mL} / \mathrm{m}^{2} /$ day during the operating period. This indicates that membrane fouling of the DM was insignificant for 18 months. An increase in transmembrane pressure on April 25, 2011, resulted in a further decrease in the concentration of D-CH${ }_{4}$ discharged from the DM reactor.

$\mathrm{R}\left(\mathrm{CH}_{4}\right)_{\text {evo }}, \mathrm{R}\left(\mathrm{D}-\mathrm{CH}_{4}\right)_{\text {col }}$, and $\mathrm{R}\left(\mathrm{D}-\mathrm{CH}_{4}\right)_{\text {dis }}$ were calculated in order to investigate the mass balance of $\mathrm{CH}_{4}$ in this system. Figure $3 \mathrm{~b}$ shows $\mathrm{R}\left(\mathrm{CH}_{4}\right)_{\text {evo }}$, $\mathrm{R}\left(\mathrm{D}-\mathrm{CH}_{4}\right)_{\text {col }}$, and $\mathrm{R}\left(\mathrm{D}-\mathrm{CH}_{4}\right)_{\text {dis }}$, and the $\mathrm{CH}_{4}$ recovery efficiency. From January to 
May 2010, no $\mathrm{CH}_{4}$ was evolved from the UASB reactor. From July to October 2010, $\mathrm{R}\left(\mathrm{CH}_{4}\right)_{\text {evo }}, \mathrm{R}\left(\mathrm{D}-\mathrm{CH}_{4}\right)_{\text {col }}$, and $\mathrm{R}\left(\mathrm{D}-\mathrm{CH}_{4}\right)_{\text {dis }}$ were $210 \pm 110 \mathrm{mg} \mathrm{COD} / \mathrm{day}, 280 \pm$ $100 \mathrm{mg} \mathrm{COD} /$ day, and $330 \pm 140 \mathrm{mg}$ COD/day, respectively. Their average rates were $0 \mathrm{mg} \mathrm{COD} /$ day, $125 \pm 20 \mathrm{mg} \mathrm{COD} /$ day, and $180 \pm 35 \mathrm{mg} \mathrm{COD} /$ day, respectively, from mid-December 2010 to March 2011. An absence of $\mathrm{CH}_{4}$ evolution was attributed to the decrease in organic matter degradation rate at lower temperatures (Figures $1 \mathrm{a}$ and 1b). The average $\mathrm{CH}_{4}$ recovery efficiency was $59 \% \pm 9 \%$ from July to October 2010 and $41 \% \pm 6 \%$ from mid-December 2010 to March 2011. The average ratio of $\mathrm{R}\left(\mathrm{D}-\mathrm{CH}_{4}\right)_{\text {col }}$ to $\mathrm{R}\left(\mathrm{CH}_{4}\right)_{\text {rec }}$ was $60 \% \pm 12 \%$ from July to October 2010 , but it was $100 \%$ during winter because no biogas was evolved into the UASB headspace. These values were greater than those in the UASB and DM reactors treating high-strength wastewater $(<35 \%)$ (Bandara et al., 2011). Thus, we concluded that degasification technology is advantageous, especially when low-strength wastewater is treated under ambient conditions in comparison to mesophilic conditions (Khan et al., 2011). However, a reduction in energy for degasification should be investigated in future studies.

$\mathrm{T}-\mathrm{R}\left(\mathrm{CH}_{4}\right)$ decreased with decreasing temperature (Figure $3 \mathrm{~b}$ ). This is attributed to the decrease in the organic matter degradation rate associated with a drop in temperature (Figures 1a and 1b) (Latif et al., 2011; Dhaked et al., 2010). As shown in Figure 3b, at low temperatures $\left(<10^{\circ} \mathrm{C}\right), \mathrm{R}\left(\mathrm{CH}_{4}\right)_{\text {evo }}$ was almost zero and $\mathrm{R}\left(\mathrm{D}-\mathrm{CH}_{4}\right)_{\text {dis }}$ was $180 \pm 35 \mathrm{mg} \mathrm{COD} /$ day from mid-December 2010 to March 2011. D- $\mathrm{CH}_{4}$ concentrations in the DM reactor were $29 \pm 9 \mathrm{mg} \mathrm{COD} / \mathrm{L}$ from July to October 
2010 and $32 \pm 9 \mathrm{mg} \mathrm{COD/L}$ from mid-December 2010 to March 2011, because the solubility of D-CH 4 increased with decreasing temperature. Consequently, the D-CH 4 collection efficiency increased relatively from $57 \% \pm 7 \%$ to $66 \% \pm 8 \%$ with a decrease in temperature. The remaining $\mathrm{D}-\mathrm{CH}_{4}$ concentrations in the effluent from the DM reactor were similar to those from the treatment of high-strength synthetic wastewaters (Bandara et al., 2011) because the same type of DM and the same transmembrane pressure were applied. Increasing the transmembrane pressure (after April 25, 2011) improved the D- $\mathrm{CH}_{4}$ collection efficiency (Figure 3b). Thus, transmembrane pressure was a critical operating parameter for the DM.

\section{Conclusions}

In this study, municipal wastewater was anaerobically treated with a bench-scale UASB reactor at ambient temperature (from $6^{\circ} \mathrm{C}$ to $31^{\circ} \mathrm{C}$ ) for 18 months. The data presented here indicated that low-strength municipal wastewaters could be treated anaerobically at ambient temperature, although COD removal efficiency is low in winter. Hydrogenotrophic methanogens were dominant under psychrophilic conditions. A DM is useful for collecting D- $\mathrm{CH}_{4}$ especially under psychrophilic conditions. From an economic point of view, a further reduction in the energy required for degasification is needed.

\section{Acknowledgements}


This research was financially supported by Core Research of Evolutional Science \& Technology (CREST) for "Innovative Technology and System for Sustainable Water Use" from the Japan Science and Technology Agency (JST) and also by funding from Hokkaido Gas Co., Ltd.

\section{References}

Alvarez, J. A., Armstrong, E., Gomez, M., Soto, M., 2008 Anaerobic treatment of low-strength municipal wastewater by a two-stage pilot plant under psychrophilic conditions. Bioresource Technology 99 (15), 7051-7062.

Andrew, D. E., Lcnore, S. C., Eugene, W. R., Arnold, B. G., 2005. Eds. Standard methods for the Examination of water and waste water, 21st, ed.; American Public Health Association: New York.

Bandara, W. M. K. R. T. W., Satoh, H., Sasakawa, M., Nakahara, Y., Takahashi, M., Okabe, S., 2011. Removal of residual dissolved methane gas in an upflow anaerobic sludge blanket reactor treating low-strength wastewater at low temperature with degassing membrane. Water Research 45 (11), 3533-3540.

Connaughton, S., Collins, G., O'Flaherty, V., 2006. Development of microbial community structure and actvity in a high-rate anaerobic bioreactor at $18^{\circ} \mathrm{C}$. Water 
Research 40 (5), 1009-1017.

Dhaked, R. K., Singh, P., Singh, L., 2010. Biomethanation under psychrophilic conditions. Waste Management 30 (12), 2490-2496.

Elefsiniotis, P., Wareham, D. G., Oldham, W. K., 1996. Particulate organic carbon solubilization in an acid-phase upflow anaerobic sludge blanket system. Environmental Science \& Technology 30 (5), 1508-1514.

Hartley, K., Lant, P., 2006. Eliminating non-renewable $\mathrm{CO}_{2}$ emissions from sewage treatment: An anaerobic migrating bed reactor pilot plant study. Biotechnology and Bioengineering 95 (3), 384-398.

Hatamoto, M., Yamamoto, H., Kindaichi, T., Ozaki, N., Ohashi, A., 2010. Biological oxidation of dissolved methane in effluents from anaerobic reactors using a down-flow hanging sponge reactor. Water Research 44 (5), 1409-1418.

Imachi, H., Sakai, S., Sekiguchi, Y., Hanada, S., Kamagata, Y., Ohashi, A., Harada, H., 2008. Methanolinea tarda gen. nov., sp nov., a methane-producing archaeon isolated from a methanogenic digester sludge. International Journal of Systematic and Evolutionary Microbiology 58, 294-301. 
Kayranli, B., Ugurlu, A., 2011. Effects of temperature and biomass concentration on the performance of anaerobic sequencing batch reactor treating low strength wastewater. Desalination $278(1-3), 77-83$.

Khan, A. A., Gaur, R. Z., Tyagi, V. K., Khursheed, A., Lew, B., Mehrotra, I., Kazmi, A. A., 2011. Sustainable options of post treatment of UASB effluent treating sewage: A review. Resources, Conservation and Recycling 55 (12), 1232-1251.

Kindaichi, T., Awata, T., Suzuki, Y., Tanabe, K., Hatamoto, M., Ozaki, N., Ohashi, A., 2011. Enrichment using an up-flow column reactor and community structure of marine anammox bacteria from coastal sediment. Microbes and Environments 26 (1), 67-73.

Latif, M. A., Ghufran, R., Wahid, Z. A., Ahmad, A., 2011. Integrated application of upflow anaerobic sludge blanket reactor for the treatment of wastewaters. Water Research 45 (16), 4683-4699.

Lettinga, G., Rebac, S., Zeeman, G., 2001. Challenge of psychrophilic anaerobic wastewater treatment. Trends in Biotechnology 19 (9), 363-370.

Lew, B., Lustig, I., Beliavski, M., Tarre, S., Green, M., 2011. An integrated UASB-sludge digester system for raw domestic wastewater treatment in temperate climates. Bioresource Technology 102 (7), 4921-4924. 
Ludwig, W., Strunk, O., Westram, R., Richter, L., Meier, H., Yadhukumar, Buchner, A., Lai, T., Steppi, S., Jobb, G., Forster, W., Brettske, I., Gerber, S., Ginhart, A. W., Gross, O., Grumann, S., Hermann, S., Jost, R., Konig, A., Liss, T., Lussmann, R., May, M., Nonhoff, B., Reichel, B., Strehlow, R., Stamatakis, A., Stuckmann, N., Vilbig, A., Lenke, M., Ludwig, T., Bode, A., Schleifer, K. H., 2004. ARB: a software environment for sequence data. Nucleic Acids Research 32 (4), 1363-1371.

Lueders, T., Friedrich, M., 2000. Archaeal population dynamics during sequential reduction processes in rice field soil. Applied and Environmental Microbiology 66 (7), $2732-2742$.

Luostarinen, S. A., Rintala, J. A., 2005. Anaerobic on-site treatment of black water and dairy parlour wastewater in UASB-septic tanks at low temperatures. Water Research 39 (2-3), 436-448.

Ma, K. Liu, X. L. Dong, X. Z., 2005. Methanobacterium beijingense sp nov., a. novel methanogen isolated from anaerobic digesters. International Journal of Systematic and Evolutionary Microbiology 55, 325-329.

Matsunaga, K. Kindaichi, T. Ozaki, N. Ohashi, A. Nakahara, Y. Sasakawa, M., 2012. Development of anammox reactor equipped with a degassing membrane to improve 
biomass retention. Water Science and Technology. in press.

Matsuura, N. Hatamoto, M. Sumino, H. Syutsubo, K. Yamaguchi, T. Ohashi, A., 2010. Closed DHS system to prevent dissolved methane emissions as greenhouse gas in anaerobic wastewater treatment by its recovery and biological oxidation. Water Science and Technology. 61 (9), 2407-2415.

McHugh, S. Carton, M. Collins, G. O'Flaherty, V., 2004. Reactor performance and microbial community dynamics during anaerobic biological treatment of wastewaters at 16-37 C. FEMS Microbiology Ecology 48 (3), 369-378.

McHugh, S. Collins, G. Mahony, T. O'Flaherty, V., 2005. Biofilm reactor technology for low temperature anaerobic waste treatment: microbiology and process characteristics. Water Science and Technology 52 (7), 107-113.

McKeown, R. M., Scully, C., Enright, A.-M., Chinalia, F. A., Lee, C., Mahony, T., Collins, G., O'Flaherty, V., 2009a. Psychrophilic methanogenic community development during long-term cultivation of anaerobic granular biofilms. The ISME Journal 3 (11), $1231-1242$.

McKeown, R. M., Scully, C., Mahony, T., Collins, G., O'Flaherty, V., 2009b. Long-term (1243 days), low-temperature $\left(4-15^{\circ} \mathrm{C}\right)$, anaerobic biotreatment of acidified 
wastewaters: Bioprocess performance and physiological characteristics. Water Research $43(6), 1611-1620$.

Nunoura, T., Inagaki, F., Delwiche, M. E., Colwell, F. S., Takai, K., 2008. Subseafloor microbial communities in methane hydrate-bearing sediment at two distinct locations (ODP Leg204) in the Cascadia Margin. Microbes and Environments 23 (4), 317-325.

Okabe, S., Satoh, H., Watanabe, Y., 1999. In situ analysis of nitrifying biofilms as determined by in situ hybridization and the use of microelectrodes. Applied and Environmental Microbiology 65 (7), 3182-3191.

O'Reilly, J., Lee, C., Chinalia, F., Collins, G., Mahony, T., O'Flaherty, V., 2010. Microbial community dynamics associated with biomass granulation in low-temperature $\left(15^{\circ} \mathrm{C}\right)$ anaerobic wastewater treatment bioreactors. Bioresource Technology 101 (16), $6336-6344$.

O'Reilly, J., Lee, C., Collins, G., Chinalia, F., Mahony, T., O'Flaherty, V., 2009. Quantitative and qualitative analysis of methanogenic communities in mesophilically and psychrophilically cultivated anaerobic granular biofilims. Water Research 43 (14), $3365-3374$.

Pauss, A., Andre, G., Perrier, M., Guiot, S., 1990. Liquid-to-gas mass transfer in 
anaerobic processes: inevitable transfer limitations of methane and hydrogen in the biomethanation process. Applied and Environmental Microbiology 56 (6), 1636-1644.

Pruesse, E., Quast, C., Knittel, K., Fuchs, B. M., Ludwig, W., Peplies, J., Gloeckner, F. O., 2007. SILVA: a comprehensive online resource for quality checked and aligned ribosomal RNA sequence data compatible with ARB. Nucleic Acids Research 35 (21), $7188-7196$.

Robertson, C. E., Spear, J. R., Harris, J. K., Pace, N. R., 2009. Diversity and stratification of archaea in a hypersaline microbial mat. Applied and Environmental Microbiology 75 (7), 1801-1810.

Saitou, N., Nei, M., 1987. The neighbor-joining method - a new method for reconstructing phylogenetic trees. Molecular Biology and Evolution 4 (4), 406-425.

Satoh, H., Miura, Y., Tsushima, I., Okabe, S., 2007. Layered structure of bacterial and archaeal communities and their in situ activities in anaerobic granules. Applied and Environmental Microbiology 73 (22), 7300-7307.

Sawajneh, Z., Al-Omari, A., Halalsheh, M., 2010. Anaerobic treatment of strong sewage by a two stage system of AF and UASB reactors. Water Science and Technology 61 (9), 2399-2406. 
Sayed, S., Dezeeuw, W., Lettinga, G., 1984. Anaerobic treatment of slaughterhouse waste using a flocculant sludge UASB reactor. Agricultural Wastes 11 (3), 197-226.

Takai, K., Horikoshi, K., 1999. Genetic diversity of Archaea in deep-sea hydrothermal vent environments. Genetics 152 (4), 1285-1297.

Tchobanoglous, G., Burton, L. B., Stensel, H. D., 2003.Wastewater Engineering: Treatment and Reuse, 4th, ed.; McGraw-Hill: New York.

Uemura, S., Harada, H., 2000. Treatment of sewage by a UASB reactor under moderate to low temperature conditions. Bioresource Technology 72 (3), 275-282.

Urban, I., Weichgrebe, D., Rosenwinkel, K. H., 2007. Anaerobic treatment of municipal wastewater using the UASB-technology. Water Science and Technology 56 (10), 37-44.

Yashiro, Y., Sakai, S., Ehara, M., Miyazaki, M., Yamaguchi, T., Imachi, H., 2011. Methanoregula formicica sp. nov., a methane-producing archaeon isolated from methanogenic sludge. International Journal of Systematic and Evolutionary Microbiology 61 (1), 53-59.

Zhang, D., Zhu, W., Tang, C., Suo, Y., Gao, L., Yuan, X., Wang, X., Cui, Z., 2012. 
Bioreactor performance and methanogenic population dynamics in a low-temperature $\left(5-18^{\circ} \mathrm{C}\right)$ anaerobic fixed-bed reactor. Bioresource Technology 104, 136-143.

Zheng, D. D., Alm, E. W., Stahl, D. A., Raskin, L., 1996. Characterization of universal small-subunit rRNA hybridization probes for quantitative molecular microbial ecology studies. Applied and Environmental Microbiology 62 (12), 4504-4513. 


\section{Figure Captions}

Figure 1a. Concentrations of influent T-COD and D-COD and effluent T-COD of the UASB reactor, and the T-COD removal efficiency of the UASB reactor. The dotted line indicates the day when the filter media was installed.

Figure 1b. Variation in temperature, HRT, and $\mathrm{pH}$ in the UASB reactor. The dotted line indicates the day when the filter media was installed.

Figure 1c. Variation in biogas production and methane gas evolution $\left.\left(\mathrm{R}_{(\mathrm{CH}}\right)_{\text {evo }}\right)$ rates into the headspace of the UASB reactor. The dotted line indicates the day when the filter media was installed.

Figure 2. Phylogenetic tree of clones obtained from the UASB reactors. The tree was generated by the maximum likelihood method. The numbers in parentheses indicate the frequencies of the identical clones analyzed. The scale bar represents the number of nucleotide changes per sequence position. The symbols at each branch point show the bootstrap values obtained from 1,000 resampling based on the neighbor-joining method (left circle) and the maximum-parsimony method (right circle). Accession numbers are also indicated. Designations at the order level are bracketed on the right. The Thermotoga spp. sequences were used as an outgroup to rooting the tree. INO and PSY represent the granular sludge inoculum and the sludge collected from the reactor after day 416 of the operation, respectively. 
Figure 3a. Variation in the D-CH 4 concentration discharged from the UASB and DM reactors. The dotted lines indicate the days when the filter media was installed (June 2010) and transmembrane pressure was increased to $97 \mathrm{kPa}$ (April 2011).

Figure 3b. $\mathrm{CH}_{4}$ evolution rate in the UASB reactor, $\mathrm{D}-\mathrm{CH}_{4}$ collection and discharge rates in the DM reactor, and $\mathrm{CH}_{4}$ recovery efficiency. The dotted lines indicate the days when the filter media was installed (June 2010) and transmembrane pressure was increased to $97 \mathrm{kPa}$ (April 2011). 


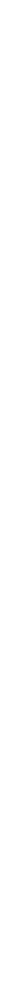

Figure 1b

Wasala et al. 


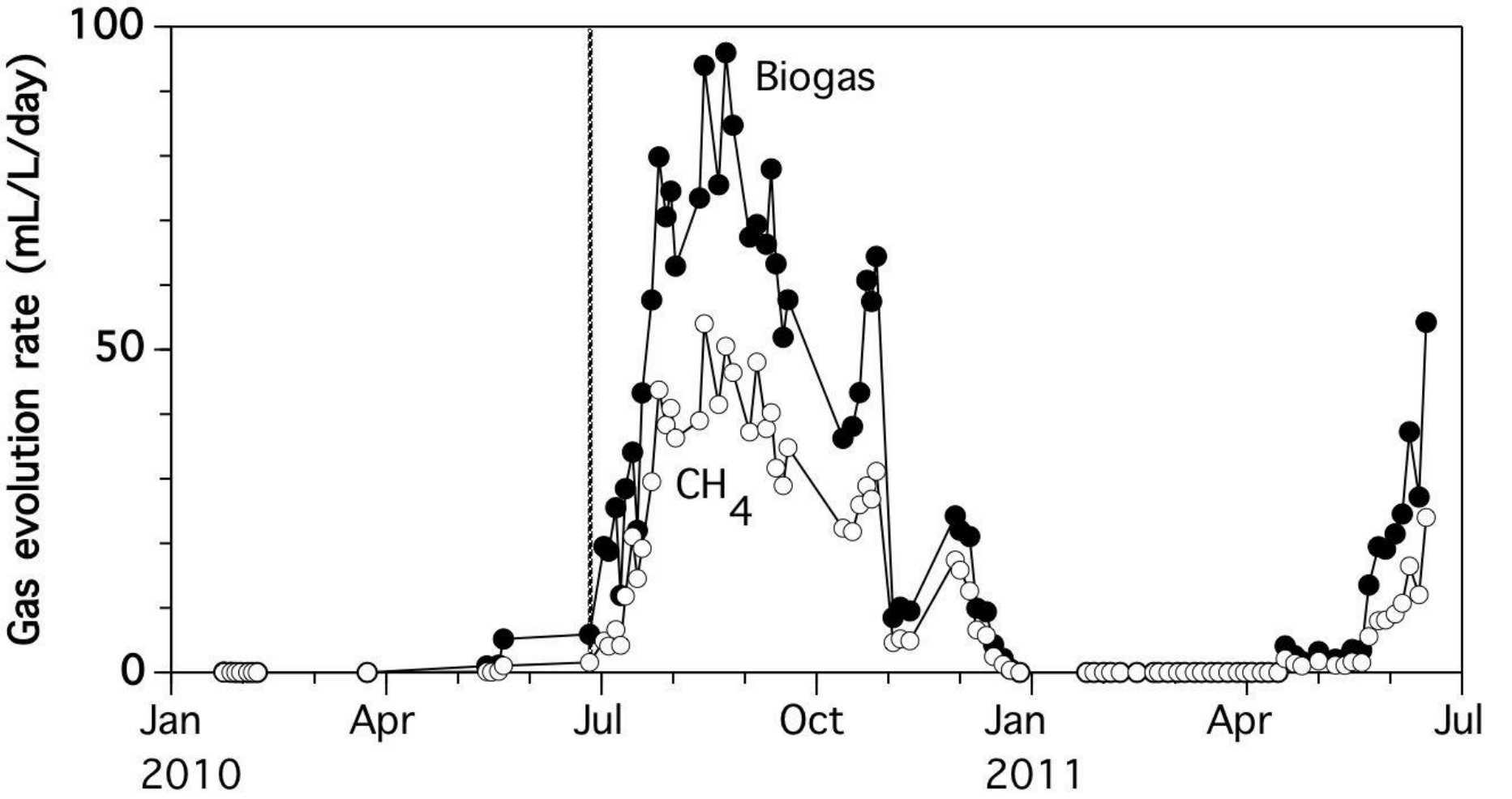

Figure 1c

Wasala et al. 


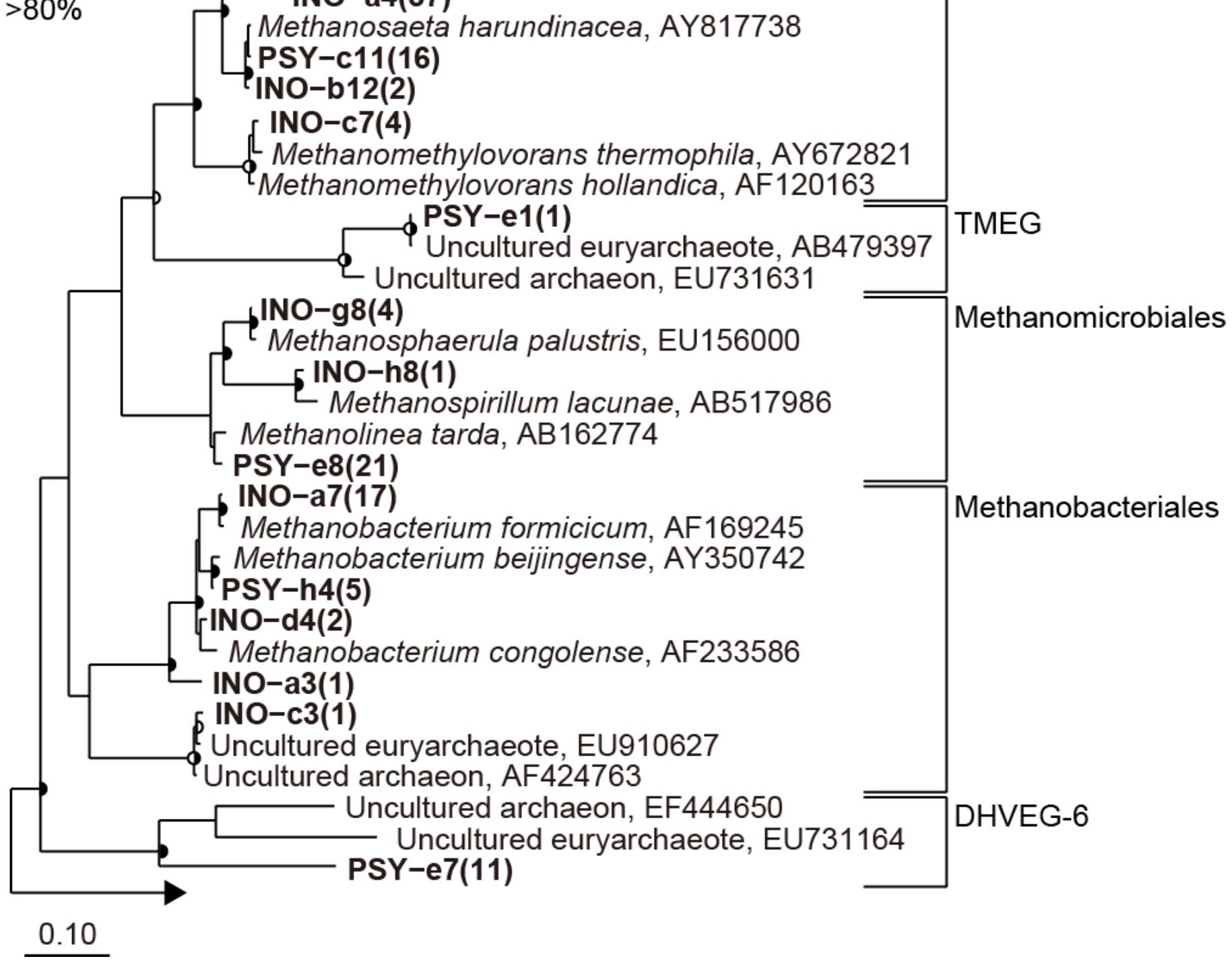

Figure 2

Wasala et al. 


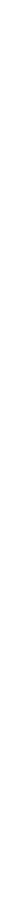

Figure $3 b$

Wasala et al. 
Table 1. A summary of the operating parameters and T-COD removal efficiencies of UASB reactors treating lowstrength wastewaters under psychrophilic conditions.

\begin{tabular}{cccccc}
\hline $\begin{array}{c}\text { COD } \\
\text { concentration } \\
(\mathrm{mg} / \mathrm{L})^{\mathrm{a}}\end{array}$ & $\begin{array}{c}\text { Organic loading rate } \\
(\mathrm{mg} \text { COD/L/day) }\end{array}$ & $\begin{array}{c}\text { Temperature } \\
\left({ }^{\circ} \mathrm{C}\right)\end{array}$ & $\begin{array}{c}\text { HRT } \\
(\mathrm{h})\end{array}$ & $\begin{array}{c}\text { T-COD removal } \\
\text { efficiency } \\
(\%)\end{array}$ & Reference \\
\hline $70-310$ & $370-3740$ & $6-31$ & $2-8$ & $8-71$ & This study \\
$690 \pm 133$ & $191 \pm 74$ & 10 & $84 \pm 20$ & $51 \pm 16$ & $\begin{array}{c}\text { Luostarinen and Rintala, 2005 } \\
\text { Sayed et al., 1984 }\end{array}$ \\
$1500-2200$ & $1500-2500$ & 20 & $18-12$ & $50-80$ & $\begin{array}{c}\text { Uemura and Harada, 2000 } \\
\text { Sawajneh et al., 2010 }\end{array}$ \\
$115-595$ & - & $13-25$ & 4.7 & 23 & Sald \\
$1247 \pm 220$ & 2560 & 15.5 & 8 & &
\end{tabular}

${ }^{\text {a }}$ COD concentrations are indicated as the lowest value-the highest value or as average \pm standard deviation. 